\title{
Will aplenty, but is there a way?
}

\section{Chicago}

As the science machinery of the former Soviet Union continues to crumble, there are no shortage of ambitious schemes to save it: last week alone, the chairman of the US House of Representatives science committee unveiled a proposal to set up a \$200-million foundation to sponsor peerreviewed research in Russia, and Administration officials revealed that they were hoping to set up several centres to find and support nondefence research for scientists now working in the country's military research centres. Among the other initiatives is a congressional bill that would spend a portion of $\$ 400$ million saved from US defence cuts to bail out Russian science, and discussions involving several private foundations as to how they can best do their part.

In an initiative unveiled last week at the annual meeting of the American Association for the Advancement of Science (AAAS) in Chicago, Representative George Brown (Democrat, California), chairman of the House Science, Space and Technology Committee, announced plans to introduce legislation that would create a $\$ 200$ million endowment to fund peerreviewed research in Russia. Called the "US/Russian Science \& Technology Foundation", Brown's proposed fund would require matching contributions (in rubles or indirect support) from the two govern- ments, much like the joint research foundations that now exist between the United States and Israel. Brown also proposed a similar foundation to support industrial research and development, providing partial funding for high technology ventures linking Russian entrepreneurs with US business partners. The science committee staff plans hearings on both initiatives later this year.

But when it comes to real money, here and now, Russian scientists appear to be far down the priority list, after food, humanitarian aid, arms control measures and economic training. Any substantial US support of basic research in the former Soviet Union appears to be a year or more away.

Even among the sectors that do have Russian science on their list, little seems likely to happen soon. Part of the problem is simply that such large efforts take time; even if the congressional bills are eventually aqproved, money is not likely to be available until next year. There is also some uneasiness about sending large sums to support Russian researchers when US researchers in many fields are struggling.

But perhaps the most difficult problem to resolve is how, exactly, to ensure that money for Russian science goes to the right people. Research in the Soviet Union has traditionally been funded in classic Soviet fashion, with a central policy-mak- ing body dividing up the science budget into block grants to various institutions. Directors of those institutions generally allocated those funds as they saw fit, which often meant that the best-connected and most politically aware scientists got the most money. Despite the political changes in the country, this is still relatively unchanged.

Many of the new proposals to aid Russian science aim to circumvent these remnants of Soviet bureaucracy. Brown's proposal, like many others now being considered, would sidestep the 'top-down' funding approach, in favour of individual grants to scientists on the merits of their research alone. He foresees a peer-review panel of Western scientists who would decide which joint US-Russian proposals to fund. This is an idea endorsed by many Russian researchers, who see outside appraisal as the only way to avoid the traditional morass of favouritism and connections. "It is most important to determine the quality of the science," Evgeny Sverdlov, director of the Moscow-based Institute for Molecular Genetics, told a panel at the AAAS meeting. "Otherwise the true scientists will be killed off and the idlers will remain because they have relatives in government."

Peer review is not an issue for Secretary of State James Baker, who is expected to offer a plan to help Russian defence

\section{Stopping the Russian nuclear brain drain}

Aвour 2,000 military scientists of the former Soviet Union are expected to be offered employment in an international scheme for the safe decommissioning of surplus nuclear weapons. The scheme is intended to discourage the scientists from accepting jobs with the armaments programmes of aggressive developing countries. An agreement was reached in principle two weeks ago at a meeting between Presidents Bush and Yeltsin in Washington.

Professor Valeri Mikhailov, publicly identified for the first time two weeks ago as the director of Russia's nuclear weapons establishment, said in Moscow that up to 15.000 specialists employed in the programme had access to classified information on plutonium production and uranium enrichment techniques and about 2,000-3,000 knew a great deal about nuclear bomb design.

The elite military scientists had until recently enjoyed considerable privileges. They now earn salaries worth less than $\$ 150$ a year at the official rate of exchange. Former Soviet weapons scientists have been offered up to $\$ 400,000$ a year by developing countries, payable through secret Swiss bank accounts, according to Augusto Forti, director-general of the Venice-based European Institute for East-West Cooperation.

Although they are still subject to a five-year ban on emigration, many observers doubt whether it is enforceable in the present state of transition. Mr Roland Dumas, the French foreign minister, has now returned from a visit to the four nuclear republics where they are employed and where he tried to persuade the authorities to enforce that ban vigorously.

The scientists are expected to be offered work by a projected new international scientific research centre. The plan coincides with warnings of the danger of radiation leaks - which Mikhailov says could turn the country into "one big Chernobyl" - arising from an inadequately executed programme for the dismantling of unwanted nuclear weapons. Britain and the United States have already promised specialist military assistance and technological support for the decommissioning programme.

The employment plan was formulated largely by Germany, Britain and the US. Mr Hans-Dietrich Genscher, the German foreign minister, has warned that the unemployed military experts are "wandering technological mercenaries" who could fall "easy prey to recruiters for irresponsible potentates with ambition to build weapons of mass destruction". Mr Richard Cheney, the American Defence Secretary, has named Iraq and North Korea as countries likely to compete for Soviet-trained scientists; Western analysts also worry about Syria, Libya and Algeria as well as Iran. Britain raised the issue at the recent Washington conference on aid to the former Soviet Union.

Foreign headhunters have already staged some well publicized operations in the former Soviet republics of Central Asia near Iran, where several military research and development complexes are based. Morale at the weapons establishments is low, with salary cuts of 40 per cent being imposed and a staff cut of up to 60 per cent expected. 
scientists when he meets Russian President Boris Yeltsin this week. Although the details of the plan are sketchy, it is expected to provide for Western-financed 'clearinghouses', in which researchers in Russia's crumbling defence industry could be matched with Western companies, research groups and government agencies that could use their talents. This approach is meant to encourage scientists to remain in Russia, and not share their weapons knowledge with developing nations.

But this proposal would apply to only a few thousand of the estimated one million scientists in the Russian research establishment. And some US policy experts are concerned that it might send the wrong message to that community. "Those researchers who made a conscious and moral choice not to work in the Soviet defence industry should not be ignored," says Harley Balzer, director of the Russian studies programme at Georgetown University in Washington, DC.

Other projects intended to help the former Soviet Union appear to ignore Russian science altogether. A bill in Congress that would give the US Agency for International Development (AID) \$645 million to provide the former Soviet Union with humanitarian and "technical" aid would not include research funds, according to Hiram Larew, a member of the AID strategic planning office. "There has been virtually no mention of research activities in the current [AID] plan" to give aid to the region, he told the AAAS panel.

One of the few concrete plans for Russian science is not coincidentally one of the smallest. The AAAS international office has decided to focus on helping Russian institutions to resume their subscriptions to foreign scientific journals. In January the Russian Academy of Sciences cut the funds for all its institutes' subscriptions, which virtually isolates most Russian researchers from developments in the West. Although several journals (including this one), have agreed to continue Russian subscriptions at cost, money for even that reduced expense is not available in Russia, and has so far been slow in coming from the West. AAAS plans to use a $\$ 2,000$ grant from the Chicago-based MacArthur Foundation to survey scientific societies and leading journals to discover how many subscriptions have been affected by the Russian measure. Association officials hope to raise several million dollars from private foundations to refill Russian bookshelves.

Despite the limitations of current proposals, there is no shortage of goodwill towards Russian science. Individual efforts from US researchers have gone as far as food shipments and personal cheques. But short of direct contact with people in Russia, there are few mechanisms to ensure that private donations will get into the right hands.

Christopher Anderson

\section{Tragedy revealed in Zurich}

\section{London}

A TRAGIC case of scientific misconduct, revealed last week by the University of Zurich, underlines the importance of ensuring that key data are replicated reliably before publication and that several members of a research team are able to carry out difficult experimental procedures.

The case centres around a claim, first published in the EMBO Journal $(9,385$; 1990), that researchers at the University of Zurich's Institute of Molecular Biology had produced functioning measles viruses by microinjecting cultured human cells with cloned complementary DNA (cDNA) produced from the RNA genome of the virus. The data underlying the claim, provided by Isidro Ballart, a South American $\mathrm{PhD}$ student working at the institute, were later found to be fraudulent. On $20 \mathrm{March}$ 1991, shortly before evidence of the fraud began to emerge, the student was found dead in his laboratory.

Martin Billeter, the leader of the research group, last autumn retracted the EMBO Journal paper as well as a second publication, based on the fraudulent data, that appeared in the Journal of Virology $(65,3161 ; 1991)$. But the university was able to reveal the case only last Friday (7 February), having been sworn to secrecy until a Zurich district attorney had completed a full inquiry into Ballart's death. His death has been ruled a suicide.

The EMBO Journal paper caused a stir among virologists. The study of negativestrand RNA viruses (in which the single strand of RNA must produce a complementary copy of itself inside the host cell before viral proteins can be transcribed) has been hindered by the lack of an experimental system for genetic manipulation. Using the model system Ballart developed, Billeter's group aimed to produce genetically engineered measles viruses by manipulating the cDNA injected into the cultured cells. Their aim was to study the function of individual measles genes, in particular the mutant genes associated with a fatal disease of the central nervous system, subacute sclerosing panencephalitis, which occurs in about one in 100,000 cases of measles.

The model system might also have allowed the production of new genetically engineered vaccines. "It would have been the most important breakthrough in our area of virology for the past 10 years," says Dan Kolakofsky, from the University of Geneva.

But the euphoria in Billeter's group came to an abrupt end with the discovery of Ballart's body. At first, it was thought he had died from natural causes. A routine examination by the university's Institute of Forensic Medicine found no evidence of poisoning. But a subsequent detailed autopsy revealed that Ballart had taken his own life by swallowing a quantity of "a common inorganic chemical", says Charles Weissmann, director of the Institute of Molecular Biology.

Meanwhile, other $\mathrm{PhD}$ students in Billeter's group were discovering that viruses purportedly produced in cell culture from cloned cDNA were no different from the standard Edmonston measles virus strain used in the laboratory. At first, nobody suspected that the dead student was guilty of fraud, instead assuming that the cell cultures must have been inadvertently contaminated with the laboratory strain. "He was very popular," says Billeter, and "always willing to help his colleagues."

But when other members of the group consistently failed to replicate Ballart's results, Billeter and his colleagues began to work systematically through the preparations left behind. The evidence pointed to one conclusion: the student had not been able to produce viable viruses by microinjecting cultured cells with cloned cDNA; instead, he had simply infected the cell cultures with the standard lab-strain virus. His genetic analyses, showing marker genes present in the cDNA, came not from viral cell culture, but from the original cDNA samples. Weissmann says that the fraud went undiscovered until other members of Billeter's group began conducting their own genetic analyses, using viruses supplied by Ballart.

In July 1991, Billeter wrote to his colleagues in the field, explaining the circumstances of the fraud; published retractions soon followed. In August, Weissmann and Billeter also pressed the university's rector to appoint an external commission to sift through the data. But the university took no further action after Clive Kuenzle, a biochemist and one of the university's pro-rectors, concluded that the evidence indicated clearly that the dead student had acted alone.

Virologists agree that Billeter was diligent in informing his colleagues in the field about the fraud. Still, the effect on Billiter's group has been debilitating: the researchers involved went through "a year of catharsis", says Kolakofsky.

The tragedy also points out the problems that can arise when experiments hinge on the performance of a difficult technique by a single relatively inexperienced researcher. For more than a year, Ballart alone was responsible for microinjecting cDNA into cultured cells and for performing the genetic analyses supposed to show that the viruses produced in the culture were derived from the cDNA. "I'm sorry that I didn't insist at the time that other members of my group also learn to do the mîcroinjection," says Billeter.

Peter Aldhous 